this bad something to do with the seizure. An embolism might be formed in the uterine sinuses and carried onwards to the brain. This is a mere speculative opinion. She could say nothing but " ta-ta" and "tut-tut" from 1883 to 1891 , and by signs and gestures lead her husband and family to understand what she wanted. My patient subsequently removed out of my district, and I never heard of her until last month, when she came to consult me and to report the marvellous change which had come about in the following way. On Saturday, Oct. 31st, 1891, she was thrown into a violent passion and much annoyed by her daughter, with whom at times she does not get on very well, and the strife lasted a considerable time. After the storm had blown over she felt a severe pain in the head, and after a short interval she found she could speak perfectly well and give expression to her feelings as plainly as ever she did in ber life. As was to be expected, the sudden change caused great consternation in her household and struck terror into the hearts of her neighbours. I had a long conversation with my patient a fortnight after the occurrence, and was most interested in her story. She is an intelligent woman and for nine years had been unable to give utterance to her thoughts. I have recorded this case at some length because I believe it to be unique, and so far as I can learn no such sudden and complete restoration of speech after so long a period of silence has ever before been recorded.

Coldstream, N.B.

\section{SOFT PAPILLOMA OF EAR OF SUSPECTED INFECTIOUS ORIGIN.}

\section{By ROBERT LAKE, F.R.C S.}

NEw growths of the external ear are, when compared with other affections of that part, somewhat uncommon; thus there did not occur more than a single case, and that not correctly speaking a growth, in 1146 consecutive cases in the aural department of St. Thomas's Hospital. ${ }^{1}$ The general position of the one described below is the usual seat of the soft variety of papillomas, ${ }^{2}$ the hard ones being also found in other situations.

The patient, a girl of short stature, aged seventeen, of dull appearance, had been subject to ostitis media purulenta for two or three years; no cause was known for its having originated. For some weeks there had been severe pain in the ear ; the discharge was most horribly offensive. On examination of the affected ear (right), the meatus was found closed by three pinkish masses, which were at first believed to be purulent collections in the subcutaneous tissue. One mass covered the posterior surface of the tragus up to the entrance to the canal; the next one sprang from the inner surface of the antitragus ; the third and largest, fully half an inch across, grew in that part of the concha adjacent to the canal, proceeding down that also for a few lines. The whole mass was covered with epithelial detritus and pus. The patient was anæsthetised, and the whole mass thoroughly scraped away wibh a curette. It was soft and bled freely; the raw surface was rubbed with a solution of chloride of zinc, sixty grains to the ounce of water; the middle ear was well disinfected and also the Eustachian tube, which was so patent that fluids flowed easily down it when the ear was syringed. Healing rapidly progressed, the raw surface being scarcely recognisable in two weeks' time.

Remarks - Although the odour and appearance of the growth were so suggestive of gonorrhoeal warts, yet no history of infection could be arrived at, and unfortunately no cultivations were made, hence the question arises whether the irritation causing the growth was an infective one or merely due to the acrid character of the discharge. The theory of infection is to a certain extent borne out by the fact that the grow ths on the tragus were obviously secondary to that on the concha, for whilst their surfaces were in contact their bases were free. Dr. Payne has shown ${ }^{3}$ that simple warts in other parts are sometimes infective, so the infection was not necessarily from the gonococcus. To the free patency of the Eustachian tube is due the absence of symptoms from plugging of the meatus externus.

Barnes, S.W.

I St. Thomas's Irospital Reports, 1889-1890.

3 British Jour. of Dermatology, vol. iii., No. 6.

\section{9. othitur}

\section{H OS P I T A L P R A C T I CE, BRITISH AND FOREIGN.}

Nulla autem est alia pro certo noscendi via, nisl quamplurimas et mon borum et dissectionum historias, tum aliorum tum proprias collecta habere, et inter se comparare.-Morgagni De Sed. et Caub. Morb. ib. iv. Procemium

\section{HUSPITAL FOR SICK CHILDREN, GREAT ORMOND-STREET.}

\section{A CASE OF COLLAPSE FROM VOMITING AND DIARRHEA} TREATED BY INTRAYENOUS INJECTION OF SALT SOLUTION.

(Under the care of Dr. STuRgEs.)

Turs case is a most important addition to those whicb have already been published as to the $\mathrm{f}$ flicacy of the injection of saline solutions where excessive loss of blood, or of the watery constituents of the blood, has taken place. It will assist in bringing before the profession in a most convincing manner the value which the treatment has in some apparently hopeless cases. Dr. B. W. Richardson ${ }^{1}$ has drawn the atten. tion of the readers of THE LANCET to the effect produced by the injection of a saline solution into the veins of a womar who was moribund from cholera collapse. "She became quite conscious, sat up in bed, and signed a shorb will." The im. provement was, however, only temporary, and required to be repeated, but each repetition was followed by the renewal of diarrhoea and cramps, and the patient died some hours later. Mr. Lane's ${ }^{2}$ experience, which was also published in THE LANCET, was derived from a case of secondary hæmorrhage and collapse after an operation for cleft palate on a girl of thirteen. The results were almost miraculous, and the child rapidly recovered. He injected three pints and a half of common salt (one drachm to the pint) into the basilic vein. We have also recorded a care under the care of Mr. Anderson ${ }^{3}$ of Nottingham, in which a fatal result from secondary bremorrhage was apparently prevented by the intravenous injection of a solution of common salt, forty grains to the pint. Eighteen ounces of this were injected, and although at the time very collapsed, within two hours "he was able to sit up and ask for his tea" An injection of twelve ounces of similar fluid was required next day after an operation to secure a wound in the popliteal artery from which the bæmorrhage had come. This was again followed by satisfactory results, and the patient, a lad of sixteen, recovered. The injection of ten ounces of a solution of phosphate of soda, twenty grains to the ounce, was employed in a natient almost moribund from loss of blood due to wounds of the neck, with immediate benefit. Before the injection the pulse was quite imperceptible at the wrist, the pupils dilated and fixed, and the conjunctivæ insensitive. A case in which much benefit of a temporary character was obtained is also recorded in our columus. It was that of a man aged fifty-four, under the care of Dr. Churton, who from excessive vomiting due to cancer of the stomach became prostrate and pulseless. Here again the improvement was very marked whenever the injections were used. Dr. Churton's remarks on his case are interesting. We have referred to the experiments of Messrs. Dastre and Lange, who say that the expression "toxic dose" has no meaning so far as the salt solution is concerned. There is no such thing as a toxic dose, but there is a toxic rapidity. Their experiments are important, and will be found in detail in the Archives de Physiologie. For the notes of this case we are indebted to Mr. Horace Collier, house physician.

W. $\mathbf{H}-$ aged nine months, was admitted to the Hospital for Sick Children, Great Ormond-street, on Oct. $26 \mathrm{th}, 1891$. For four months he had been under care as an out-patient for congenital syphilis and rickets, witt several attacks of diarrhoea. He was, upon admission, cold, pale, shrivelled-looking, completely quiet, and with sunken eyes and hollow-looking orbits. The history was that there had been severe diarrboa and repeated vomiting for two days.

The child was at once rendered warm, and brandy

1 The LanCET, vol. ii. 1891, p. 701. See also the Asclepiad, 4th quarter, 1891, p. 335 .

1891, p. ${ }_{2}$ Ibid., vol. ii. 1891, p. $626 . \quad$ 3 Ibid., vol. i. 1889, p. 829. 